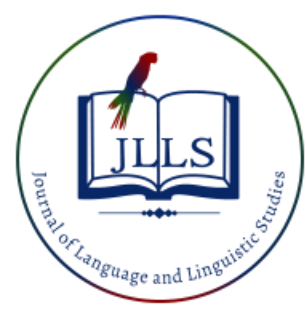

Available online at www.jlls.org

JOURNAL OF LANGUAGE AND LINGUISTIC STUDIES

ISSN: $1305-578 \mathrm{X}$

Journal of Language and Linguistic Studies, 16(4), 1952-1967; 2020

\title{
The relationship between critical thinking dispositions of prospective English language teachers and their levels of new media literacy*
}

\author{
Aslı Yaren Yüzgeç a iD, Selim Soner Sütçü b ${ }^{\text {b }}$ iD \\ ${ }^{a}$ TED University, Ankara, Turkey \\ ${ }^{b}$ Başkent University, Ankara, Turkey

\section{APA Citation:} \\ Yüzgeç, A. Y. \& Sütçü, S. S. (2020). The relationship between critical thinking dispositions of prospective English language teachers and their \\ levels of new media literacy. Journal of Language and Linguistic Studies, 16(4), 1952-1967. \\ Submission Date:12/09/2020 \\ Acceptance Date:25/09/2020
}

\begin{abstract}
The teaching profession, by its very nature, requires teachers to develop themselves continuously, to keep up with the innovations emerging over time, to acquire the competencies they require, and hence keep themselves updated. In our time, in which the developments have gained an enormous pace, particularly in technology, this requirement has become vital for teachers whose contributions to shape societies are immense. With the recent advances in technology, it has become of great importance for teachers to learn the emerging new media culture and use them effectively in their lessons. On the other hand, as a result of these rapid developments, the acquisition of critical thinking, which dates back to ancient times as a concept, by teachers as a skill has become more important than ever before. At this point, there are evaluations made regarding the importance of these two skills primarily in teacher training programs. In line with these evaluations, this study examined the relationship between the critical thinking dispositions (CTD) and their new media literacy levels (NML) of pre-service English teachers studying at the education faculties of two foundation universities. Results showed that the candidates participating in the research have high level critical thinking and new media literacy skills, and there is a moderate positive relationship between these two skills.
\end{abstract}

(C) 2020 JLLS and the Authors - Published by JLLS.

Keywords: critical thinking disposition; new media literacy; English language teaching

\section{Introduction}

Teachers have many different roles that require responsibilities in society although each of them has many various features. Some of these roles are teaching knowledge, creating a pleasant learning environment, role modelling and mentoring while others are having excellent communication skills, deep knowledge and passion for their subjects, the ability to build healthy relationships with their students, being friendly and approachable, having preparation and organisation skills and strong work ethic. These roles and features may be shaped in accordance with 21 st century skills and they may vary

\footnotetext{
${ }^{1}$ Corresponding author.

E-mail address: ssoner@baskent.edu.tr

*This article has been produced from the master's thesis of the first author under the supervision of the second author.
} 
from person to person. Every teacher has unique features, and these features form their personalities. There lie people's dispositions and skills under these personalities. There are many different thinking styles, and critical thinking is one of them. Nickerson (1988) states that thinking skills involve problemsolving, decision-making, critical thinking, logical judgment and creative thinking. Critical thinking is specifically important and has been investigated up to today.

With people's changing demands all over the world, thinking inevitably requires some technological components as it is a digital era. Media literacy is one of the most commonly used literacies, especially among language teachers. It is a must for an efficient language learning \& teaching environment. The development of media itself has made a significant contribution to media literacy over time. The rapid changes of technology and digital sources along with people's attention to and awareness of the media are some reasons for the growth of media literacy. It is relatively a new profession area to study; however, it is rapidly growing, so there need to be more researches about media literacy. Media literacy principally consists of some certain aptitudes, such as attaining, investigating, assessing, and reaching out media messages in several ways (Huguet, Kavanagh, Baker, \& Blumental, 2019). It is incredibly essential to search, access, identify, gather, synthesis, evaluate and choose correct information from many sources. Media literacy is a broad term, so it can be connected with digital literacy, visual literacy, science literacy, and some other related literacies. Media literacy term is also used equivalently with media education or media literacy education, which means they mean the same thing (Chen, 2007).

\subsection{Literature review}

\subsubsection{Critical thinking}

There are many different thinking styles and this research focuses on one of them, critical thinking. Lipman (1988) expressed that critical thinking is inequivalent to ordinary thinking by giving some examples; for example whereas 'guessing' is ordinary, estimating is critical and whereas 'believing' is ordinary, 'assuming' is critical and whereas 'supposing' is ordinary, 'hypothesising' is critical. In the 21 st century, it is a requirement for every individual to have this skill. According to Paul and Elder (2014), people need to investigate and make a comment on the actions happening around them. Critical thinking deals with how to think whereas thinking deals with what to think. They also add that everyone thinks they have it in their anatomy; however critical thinking takes place as soon as people begin considering about 'thinking' with the intention of making it better. There are many ideas about critical thinking but not a specific definition. The word 'critical' derived from the Greek word Kritikos and it means 'to judge'. According to Cüceloğlu (1995, as cited in Azar, 2010), critical thinking is a systematic mind-set that takes place in people's lives to make them gain the awareness of observing others and their inner voices consciously. Halpern (2003) defined critical thinking as a contemporary skill which has a purpose and is rationalised, and aim-oriented - type of thinking which contains dealing with problems, understanding assumptions, predicting possibilities, and deciding when the thinking person knows what idea is the best for that specific setting and process. According to her, critical thinking involves these skills: judging, discussing, higher thinking skills such as theorizing, deciding and answering. Critical thinking skills, or what some others name as higher-order thinking, promote learners link knowledge when they utilise information from several alternative sources and experiences to achieve generous amount perspective and profound mind-set (Kanı, 2010). It is known that critical thinking involves both critical thinking skills and CTD. Critical thinking skills and CTD are two different dimensions. Some scholars include critical thinking skills and CTD in the definition of critical thinking whereas some scholars agree that thinking critically and having the disposition to think critically differ from each other (Ennis, 1985). One person might have critical thinking skills, but it does not show that person uses these skills. It depends on the disposition to do it. In other words, critical thinking has been seen as dependent upon its disposition by many researchers. CTD is a commonly used 
approach in education. It is seen as a must by many scholars for language teachers as language comes with the culture of that language. Thinking critically about a topic is to evaluate that topic from different point of views, to take a gander at any potential presumptions dominating the topic and to investigate its potential other options (Halvorsen, 2005). It is thinking about thinking. Thinking critically is a skill that not everybody has. So, a language teacher must analyse both the language and culture and should be competent enough to use this perspective as a teaching tool in his/her own classes. In this changing world, CTD is a very important skill, especially for educators; because teachers reflect their ideas and tendencies to their students. If human societies want to alter the way they are, they need to renovate their teachers' critical thinking skills.

\subsubsection{Media literacy}

With the altering digital world in our era, media are becoming more important day by day. Traditional media forms have become more obtainable thanks to all these alterations in today's world. Media literacy term is not originally a new term; it has occurred since the beginning of the 20th century. Media have been one of the most used tools in the growing world. With changing technology, there have occurred many different literacies. Wade (2014) points out that there are many academic works which have investigated the "new" literacies that are requirements of today's society and these literacies are information literacy, computer literacy, (new) media literacy, and visual literacy. Scheibe and Rogow (2008) define that media literacy is the competence of someone to reach, investigate, analytically assess, and create messages in many different ways. Technology has changed the things that we need to learn and the way how we learn them. The European Commission (2009) expressed the definition of media literacy as the competency of reaching the media, assuming and to assessing varying perspectives of the media and media packs and communicating varyingly. Media literacy enhances the smart use of media, supports individuals' differentiating and analysing media and makes creating new media content easy for individuals (Kellner \& Share, 2007). There are some skills that people need to have so as to have media literacy if they want to be individuals who are active and show participation in society and use media competently (Jenkins et al., 2006). These core media literacy skills are;

- Play is the ability to try different things with a person's environmental factors as a type of problem-solving.

- Performance is the capacity to embrace other characters to spontaneously create and find out new things.

- Simulation is the capacity to decipher and build simulations of real-life related issues.

- Appropriation is the capacity to consciously test and combine media content.

- Multitasking is the capacity to examine one's condition and move centre to other important aspects.

- Distributed Cognition is the capacity to connect knowingly with devices that extend intellectual abilities.

- Collective Intelligence is the capacity to collect information and contrast details with others towards a shared objective.

- Judgment is the capacity to assess the accuracy and believability of various data sources.

- Transmedia Navigation is the capacity to easily understand the progression of different knowledge.

- Networking is the capacity to look for, incorporate and disperse data. 
- Negotiation is the capacity to carry information, observing and honouring different points of view, understanding and following other standards.

- Visualization is the capacity to decipher and make information portrayals to communicate thoughts, discovering designs, and revealing patterns.

Just like critical thinking, media literacy is also one of the 21 st century skills. It has been increasingly demanded in societies. Every individual must gain this skill if they want to catch up with the requirements of the era and to be an active part of society. When the first TV, radio, telephone took place in everyday life, it interested the mass society. It was considered that there was a possibility of using these tools for educational purposes in the USA and Europe. The educators realised that these tools were a good way of attracting learners. They utilised films and TV programmes, music, photos, billboards in the past as a helpful way of teaching for so long and they still use these tools as educational tools (Chen, 2007). Many schools have many educational media, and they are used for all subjects (Buckingham, et al., 2005). Media foster both creative and critical thinking in a subject. Using media in classrooms lead students to think more creatively and critically about the topic. One of the reasons for this is that from using the World Wide Web (WWW) to using papers in the classroom takes the attention of the students. Media are becoming more and more available for people, and it makes it easy to use media as a way of promoting learning by teachers (Kellner \& Share, 2005). The first attempts at using media for educational purposes started in English classes. What is more, the media education teachers are firstly raised as English teachers, and then they continue teaching both of them or only English. This has been one of the reasons why using media in English classes is essential and appropriate (Buckingham, et al., 2005). According to Willis, Weiser \& Kirkwood (2014), using media in classrooms has many benefits in terms of having an interactive classroom environment while teaching. If teachers manage to use media effectively, it can improve the relationships and learning, and it increases the numbers of the students who participate in lessons. When instructors apply the bilateral media in their teaching on purpose, it likewise assists students to develop and make use of the limitless resources during their learning process both inside and outside the classroom (Willis, Weiser \& Kirkwood, 2014).

\subsubsection{Studies related to critical thinking skills and media literacy}

Feuerstein (1999) wrote an article which aimed to research how media literacy education programs affect the improvements of critical thinking, with a group of 273 students aged at 10-12. The researcher used a mixed method consisting of questionnaires, interviews, and research and control groups in a pretest and post-test research design. The control group consisted of 154 pupils, and the research group consisted of 119 pupils. The teacher of the control group was educated by a media literacy expert. The teacher of the control group did not take place in any media literacy program and conducted the usual curriculum. The study resulted that media literacy had great help in the improvement of critical thinking skills of the pupils. Arke (2005) did a research named "Media Literacy and Critical Thinking: Is There a Connection?". He used a demographic survey and a test to measure both skills of undergraduate college students. He used the survey that he developed to measure media literacy, and The California Critical Thinking Skills Test (CCTST) was used to measure critical thinking. The research resulted in a significant positive relationship between media literacy and critical thinking skills of college students.

Similarly, in their research, Erdem \& Erişti (2018) investigated the relationship between prospective teachers' levels of media literacy skills and critical thinking dispositions. 517 prospective teachers from different programmes and grades were the participant group. The study yielded that the relationship between prospective teachers' levels of media literacy skills and critical thinking dispositions was medium-level positive. Also, Aybek (2016) examined the relationship between prospective teachers' media and television literacy and their critical thinking dispositions. The quantitative research method was used to collect the data. There were 166 prospective teachers from different programmes and grades 
in the participant group. There was a medium level positive relationship between prospective teachers' critical thinking dispositions and their media and television literacy levels.

\subsection{Research questions}

In the literature, there are some studies that examined the relationship between teachers' CTD and other variables. However, there is a gap in the relationship between CTD of prospective English language teachers and their media literacy skills. In other words, the relationship between CTD of these students and how much they are literate in media has not been studied. So it can be said that this study will contribute to this limited literature. So the purpose of this study is to investigate whether there is a relationship between CTD of prospective English language teachers and their levels of media literacy and if there is, how much these two variables are related to each other. For this purpose, the following research questions were raised.

1. What are the critical thinking dispositions of prospective English language teachers?

2. What are the new media literacy levels of prospective English language teachers?

3. Is there any significant relationship between critical thinking dispositions of prospective English language teachers and their levels of media literacy?

4. If there is a relationship between critical thinking dispositions of prospective English language teachers and their levels of media literacy, to what extent is there a relationship?

\section{Method}

\subsection{Participants}

The main respondents and participants of this research are university students from two foundation universities. These students are the students of the department of English language teaching. The students are 1st, 2nd, 3rd and 4th degree students. They are the students who have been studying during the 2019-2020 Spring Term. In the study, there are 31 male students (23\%) and 104 female students (\%77). There are 341 st grade students (25.2\%), 37 2nd grade students (27.4\%), 21 3rd grade students $(15.6 \%)$ and 43 4rd grade students $(31.9 \%)$.

\subsection{Instruments}

This study has been a quantitative research study, and the data have been gathered through two different instruments. They have been used in the past by many researchers and it has been proven that they are strong tools when the researchers need to access to opinions of a wider community (Patton, 2005). One of these two questionnaires has been for CTD and the other one has been for media literacy level. Particularly, CTD Scale (Semerci, 2016) and New Media Literacy Scale (Yavuz, 2018) are used as the method of measuring the relationship between CTD of prospective English language teachers and their levels of media literacy to attain the deeper knowledge.

CTD Scale by Semerci is very similar to California CTD Inventory-Turkish which was developed by Kökdemir in 2003 and have been used by many researchers in the Turkish context. CCTDI was originally invented by Peter A. Facione, Noreen C. Facione in 1992 and have been used many times by many researchers. In CTD Scale by Semerci, there are 49 questions aiming to assess the CTD of prospective English language teachers. In this questionnaire, the questions have been presented in the form of items for prospective teachers to comment on a five-point Likert-type scale ranging from "totally 
disagree" to "totally agree." 1 means totally disagree while 5 means totally agree. This scale is multidimensional. There are 49 items and five subscales: metacognition (14 items), flexibility (11 items), systematicity (13 items), tenacity-patience ( 8 items) and open-mindedness ( 3 items). The necessary permission was obtained from Semerci (2016) to use this survey via e-mail.

NMT Scale, consisting of 60 items, was developed by Literat in 2014. She developed the scale in accordance with Jenkins' theoretical framework. The questions in this scale also have been presented in the form of items for prospective teachers to comment on a five-point Likert-type scale ranging from "strongly disagree" to "strongly agree". There are 5 scores for each question. 1 means strongly disagree while 5 means strongly agree. Yavuz (2018) translated this questionnaire into Turkish and used it in her own master thesis to assess NMT skills of prospective teachers. There are 40 questions in the Turkish version and this version was used in this study. There are 40 items and eleven sub-scales: play ( 3 items), simulation (3 items), performance ( 2 items), appropriation (3 items), distributed cognition (4 items), multitasking (4 items), judgement (4 items), transmedia navigation (4 items), networking (4 items), negotiation (4 items), and visualization (4 items). The necessary permission was obtained from Literat (2014) and Yavuz (2018) to use this survey via e-mail.

\subsection{Data collection procedures}

Before the questionnaires were implemented to the participants, the required permission was obtained from the rectorates of both universities. The implementation of the study was planned to be face to face; however, because of Covid-19 pandemic conditions, the study had to be implemented online. The participants were informed about the purpose of the study before the questionnaires were implemented and participation of the study would be voluntary. They were also informed that all the data would be used only for research study and the results would be kept confidential. The study was implemented during the 2019-2020 academic year, spring term. The questionnaires were delivered to the students by the lecturers of the faculty of education and answered by the prospective English language teachers individually and online due to the current situation.

\subsection{Data analysis}

Analyses were made through IBM SPSS Statistics 23 package program. While evaluating the study data, frequencies (number, percentage) were given for categorical variables and descriptive statistics (mean, standard deviation, minimum, maximum) were given for numerical variables. The normality assumption of numerical variables was examined with the Kolmogorov Smirnov normality test and it was found to be normally distributed. For this reason, parametric statistical methods were used in the study. Relationships between two independent numerical variables were interpreted by Pearson Correlation coefficient. The differences between the two independent groups were examined by Independent Sample T Test and the differences between more than two independent groups were examined by One Way Variance Analysis (ANOVA). Tukey multiple comparison test was used because there was difference in the result of One Way Variance Analysis (ANOVA). Statistical significance was interpreted at the level of 0.05 in the analyses.

\section{Results}

The first question of the research was "What are the critical thinking dispositions of prospective English language teachers?". Table 1 shows average scores of critical dispositions of prospective English language teachers. 
Table 1. The average scores of the CTD of prospective English language teachers

\begin{tabular}{lcccccc}
\hline & Average & $\begin{array}{c}\text { Standard } \\
\text { Deviation }\end{array}$ & Minimum & Maximum & $\begin{array}{c}\text { Item } \\
\text { Number }\end{array}$ & $\begin{array}{c}\text { Cronbach } \\
\text { Alfa }(\alpha)\end{array}$ \\
\hline Metacognition & 4,19 & 0,459 & 3,14 & 5,00 & 14 & 0,803 \\
Flexibility & 4,15 & 0,501 & 2,73 & 5,00 & 11 & 0,796 \\
Systematicity & 3,99 & 0,542 & 2,54 & 5,00 & 13 & 0,820 \\
Tenacity Patience & 3,89 & 0,717 & 1,63 & 5,00 & 8 & 0,830 \\
Open-Mindedness & 3,90 & 0,689 & 1,00 & 5,00 & 3 & 0,581 \\
Critical Thinking Disposition & 4,02 & 0,483 & 2,37 & 5,00 & 49 & 0,939 \\
\hline
\end{tabular}

As indicated in Table 1, the metacognition average of participants is $4.19 \pm 0.459$, Flexibility $4.15 \pm$ 0.501 , Systematicity $3.99 \pm 0.542$, Tenacity Patience $3.89 \pm 0.717$, Open-Mindedness $3.90 \pm 0.689$ and CTD average is 4.02. \pm is 0,483 which means that prospective English language teachers have a high level of CTD.

The second question of the research was "What are the new media literacy levels of prospective English language teachers?". Table 2 shows the average scores of NMT levels of prospective English language teachers.

Table 2. The average scores of NMT levels of prospective English language teachers.

\begin{tabular}{|c|c|c|c|c|c|c|}
\hline Play & 3,99 & 0,821 & 1,00 & 5,00 & 3 & 0,712 \\
\hline Simulation & 4,18 & 0,704 & 2,33 & 5,00 & 3 & 0,570 \\
\hline Performance & 2,97 & 1,185 & 1,00 & 5,00 & 2 & 0,597 \\
\hline Appropriation & 4,12 & 0,718 & 2,00 & 5,00 & 3 & 0,567 \\
\hline Distributed Cognition & 4,18 & 0,586 & 2,00 & 5,00 & 4 & 0,550 \\
\hline Multitasking & 3,63 & 0,992 & 1,00 & 5,00 & 4 & 0,783 \\
\hline Judgement & 4,30 & 0,592 & 2,50 & 5,00 & 4 & 0,728 \\
\hline Transmedia Navigation & 3,96 & 0,871 & 1,25 & 5,00 & 4 & 0,693 \\
\hline Networking & 3,36 & 1,092 & 1,00 & 5,00 & 4 & 0,835 \\
\hline Negotiation & 4,17 & 0,746 & 1,80 & 5,00 & 5 & 0,820 \\
\hline Visualization & 4,34 & 0,615 & 2,00 & 5,00 & 4 & 0,644 \\
\hline NML & 3,93 & 0,460 & 2,26 & 4,80 & 40 & 0,889 \\
\hline
\end{tabular}

As shown in Table 2, the play average of participants is $3.99 \pm 0.821$, Simulation $4.18 \pm 0.704$, Performance $2.97 \pm 1.185$, Appropriation $4.12 \pm 0.718$, Distributed Cognition $4.18 \pm 0.586$, Multitasking $3.63 \pm 0.992$, Judgment 4.30 $\pm 0,592$, Transmedia Navigation $3.96 \pm 0.871$, Networking $3.36 \pm 1.092$, Negotiation $4.17 \pm 0.746$, Visualization $4.34 \pm 0.615$ and the average of NML is $3.93 \pm 0.460$. It can be said that prospective English language teachers have high level of NMT.

The third question of the research was "Is there any significant relationship between critical thinking dispositions of prospective English language teachers and their levels of media literacy?". Table 3 shows the relationship between CTD of prospective English language teachers and their levels of media literacy. 
Table 3. The relationship between CTD of prospective English language teachers and their levels of media

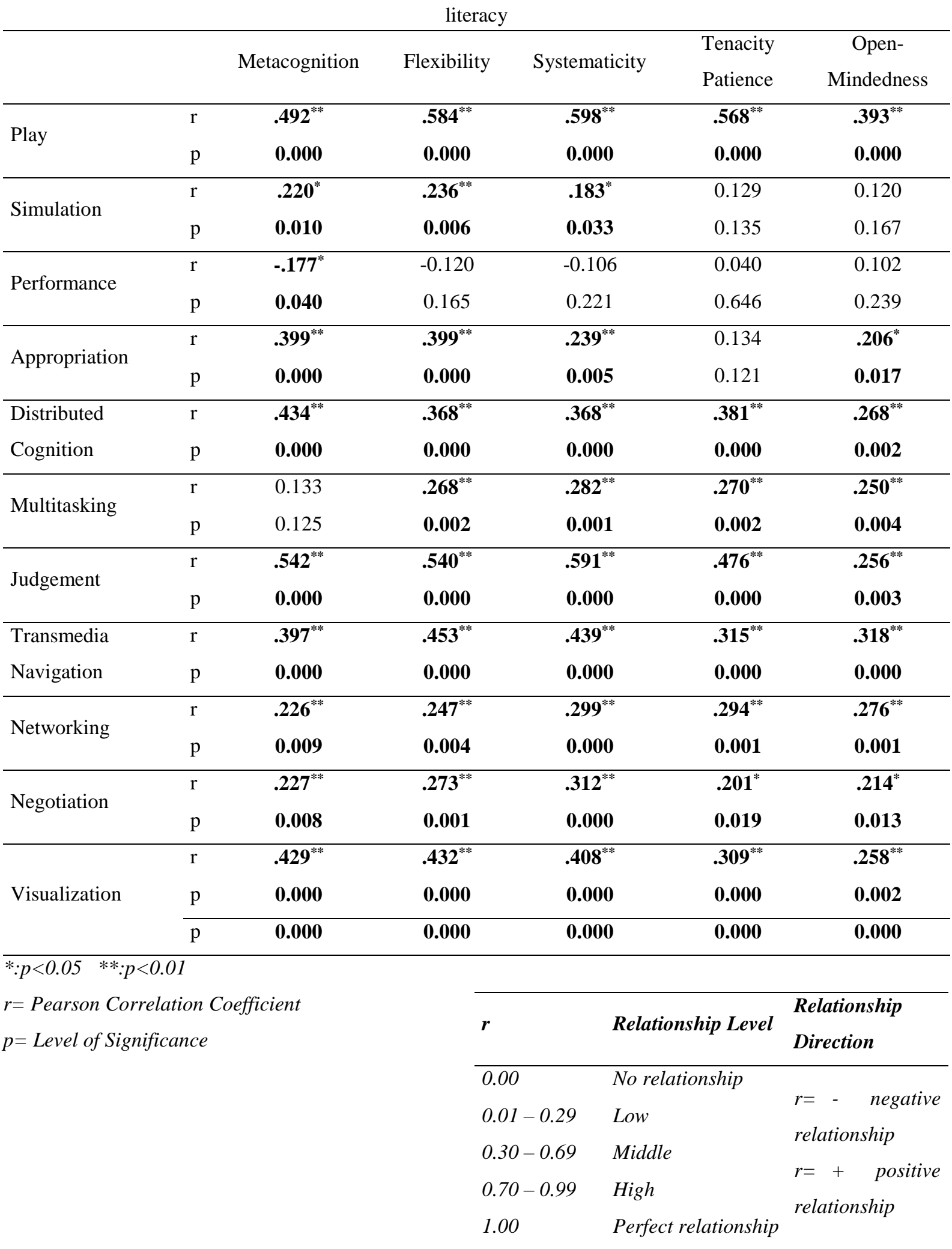

As demonstrated in Table 3 there is a moderately positive and statistically significant relationship between:

- Play scores and Metacognition, Flexibility, Systematicity, Tenacity Patience, OpenMindedness, CTD scores. 
- Appropriation scores and Metacognition, Flexibility, CTD scores. There is a low level of positive and statistically significant relationship between Appropriation scores and Systematicity, Open-Mindedness scores.

- Distributed Cognition scores and Metacognition, Flexibility, Systematicity, Tenacity Patience, CTD scores. There is a low level of positive and statistically significant relationship between Distributed Cognition scores and Open-Mindedness scores.

- Judgment scores and Metacognition, Flexibility, Systematicity, Tenacity Patience, CTD scores. There is a low level of positive and statistically significant relationship between Judgement scores and Open-Mindedness scores.

- Transmedia Navigation scores and Metacognition, Flexibility, Systematicity, Tenacity Patience, Open-Mindedness, CTD scores.

- Negotiation scores and Systematicity scores.

- Visualization scores and Metacognition, Flexibility, Systematicity, Tenacity Patience, CTD scores. There is a low level of positive and statistically significant relationship between Visualization scores and Open-Mindedness scores.

- NMT scores and Metacognition, Flexibility, Systematicity, Tenacity Patience, OpenMindedness, CTD scores.

There is a low level of positive and statistically significant relationship between:

- Simulation scores and Metacognition, Flexibility, Systematicity, CTD scores.

- Multitasking scores and Flexibility, Systematicity, Tenacity Patience, Open-Mindedness, CTD scores.

- Networking scores and Metacognition, Flexibility, Systematicity, Tenacity Patience, OpenMindedness scores. There is a moderately positive and statistically significant relationship between Networking scores and CTD scores.

- Negotiation scores and Metacognition, Flexibility, Tenacity Patience, Open-Mindedness scores.

There is a low level of negative and statistically significant relationship between

- Performance scores and Metacognition scores.

The results indicate that CTD and NML of for prospective English language teachers are related to each other. The sub-dimensions in table 3 represent different skills. Though individuals might have some of the skills of CTD and NML; however they are still critical thinker and media literate if they use it. They are both vital for a teacher in other words, a good teacher must be able to think critically and be media literate. They both complement each other in a classroom environment. A teacher who have high level of CTD is never enough for his/her students if he/she cannot use media appropriately. Teachers need the support of media to teach their subjects. To choose the best media, teachers need to be media literate.

The fourth question of the research was "If there is a relationship between CTD of prospective English language teachers and their levels of media literacy, to what extent is there a relationship?". Table 4 shows the extent of relationship between CTD of prospective English language teachers and their levels of media literacy. 
Table 4. The extent of relationship between CTD of prospective English language teachers and their levels of media literacy.

\begin{tabular}{|c|c|c|c|c|}
\hline & & \multicolumn{3}{|c|}{ NML } \\
\hline \multirow{2}{*}{ CTD } & $\mathrm{r}$ & & $.583^{* *}$ & \\
\hline & $\mathrm{p}$ & & 0.000 & \\
\hline$*: p<0.05 \quad * *: p<0.01$ & & & & \\
\hline$r=$ Pearson Correlation Coefficient & & $\boldsymbol{r}$ & Relationship Level & $\begin{array}{l}\text { Relationship } \\
\text { Direction }\end{array}$ \\
\hline$p=$ Level of Significance & & 0.00 & No relationship & \\
\hline & & $0.01-0.29$ & Low & $r=-$ negative \\
\hline & & $0.30-0.69$ & Middle & retamonstip \\
\hline & & $0.70-0.99$ & High & relationshin \\
\hline & & 1.00 & Perfect Relationship & \\
\hline
\end{tabular}

As seen in Table 4 there is a moderately positive and statistically significant relationship between CTD scores and NML scores $(r=0.583)$.

\section{Discussion}

The primary aim of the study was to investigate the relationship between CTD of prospective English language teachers and their levels of media literacy. The findings indicated that the average of the CTD scores of prospective English language teachers $(4.02 . \pm 0,483)$ are high which means that prospective English language teachers have a high level of CTD. A similar finding was also found in the average of the NMT scores of prospective English language teachers $(3.93 \pm 0.460)$, which, again, indicates that prospective English language teachers have a high level of NMT. The examination of the relation between critical thinking dispositions and levels of media literacy of prospective English language teachers yielded a positive and significant difference.

The results of this study are consistent with the related literature. Arke (2005) found a significant positive relationship between media literacy scores and CTD scores, similarly Aybek (2016), found a medium level positive relationship between prospective English teachers' general CTD scores and the media and television literacy scale literacy sub-dimensions. Also, Erişti and Erdem (2018) found a medium level positive relationship between prospective English teachers' CTD and media literacy levels. Also, in the study it was observed that prospective English language teachers have a high level of CTD and NMT levels which is in parallel with the results of Yavuz (2018).

\section{Conclusions}

In the $21^{\text {st }}$ century, both CTD and NMT skills have become vital for teachers. As indicated in this study, they are related to each other, and this relation makes them more important since both CTD and NMT skills complement to each other and thus, use of them together in class maximises the learning. When it comes to language teaching, a teacher not only teaches the language but also teaches the culture of the language. To internalize all components of the language, only thinking is not enough; thinking about thinking gains importance. On the other hand, the media has gained more importance than ever before with ever increasing types and numbers and has assumed an important part in everyday lives of 
all the people. This is also reflected in education with the new forms of media promising new benefits for teaching, specifically language teaching. They are also welcomed by the learners of this century since they are directly born in those developments and expect to use them in every part of their lives including school. Therefore, having critical thinking skills, being media literate and using these skills in language classes have become the primary competencies for the teachers of this century.

\section{Ethics Committee Approval}

The authors confirm that the study does not need ethics committee approval according to the research integrity rules in their country (Date of Confirmation: Sep 09, 2020).

\section{References}

Arke, E. (2005). Media literacy and critical thinking: Is there a connection? (Unpublished doctoral dissertation). Duquesne University, Pittsburgh, Pennsylvania.

Aybek, B. (2016). The relationship between prospective teachers' media and television literacy and their critical thinking dispositions. Eurasian Journal of Educational Research, 63, 261-278.

Azar, A. (2010). The effect of critical thinking dispositions on students' achievement in selection and placement exam for university in Turkey. Journal of Turkish Science Education, 7(1), 62-73.

Buckingham, D., Banaji, S., Burn, A.Carr, D. (2005). The media literacy of children and young people: a review of the academic research, London: Ofcom.

Chen, G. M. (2007). Media (literacy) education in the United States. China Media Research, 3(3), 87103.

Ennis, R. H. (1985). A logical basis for measuring critical thinking skills. Educational Leadership, $43(2), 44-48$

Erdem, C., \& Erişti, B. (2018). The relationship between prospective teachers' levels of media literacy skills and critical thinking dispositions. Electronic Journal of Social Sciences, 17(67), 1234-1251.

Facione, P. A., Facione, N. C. (1992). California Critical Thinking Disposition Inventory: CCTDI Inventory Manual. Millbrae, CA, California Academic Press.

Feuerstein, M. (1999). Media literacy in support of critical thinking. Journal of Educational Media, 24(1), 43-54.

Halpern, D. F. (2003). Thought and knowledge (5th ed.). New York, NY: Psychology Press.

Halvorsen, A. (2005). Incorporating critical thinking skills development into ESL/EFL Courses (TESL/TEFL). The Internet TESL Journal, 11(3), 1-5.

Huguet, A., Kavanagh, J., Baker, G., \& Blumental, M. (2019). Exploring media literacy education as a tool for mitigating truth decay. Santa Monica, Los Angeles, CA: RAND Corporation.

Jenkins, H., Clinton, K., Purushotma, R., Robison, A. J., \& Weigel, M. (2006). Confronting the challenges of participatory culture: Media education for the 21st century. MacArthur Foundation.

Kanık, F. (2010). An assessment of teachers' conceptions of critical thinking and practices for critical thinking development at seventh grade level (Unpublished doctoral dissertation). Middle East Technical University, Ankara, Turkey. 
Kellner, D., \& Share, J. (2005). Toward critical media literacy: Core concepts, debates, organizations, and policy. Discourse: studies in the cultural politics of education, 26(3), 369-386.

Kökdemir, D. (2003). Belirsizlik durumlarında karar verme ve problem çözme (Unpublished doctoral dissertation). Ankara University, Ankara, Turkey.

Lipman, M. (1988). Critical thinking: What can it be? Educational Leadership, 1, 38-43.

Literat, I. (2014). Measuring new media literacies: Towards the development of a comprehensive assessment tool. The National Association for Media Literacy Education's Journal of Media Literacy Education, 6(1), 15-27.

Nickerson, R. S. (1988). On improving thinking through instruction. Review of Research in Education, 15(1), 3-57.

Patton, M. Q. (2005). Qualitative research. New York: John Wiley \& Sons, Ltd.

Paul, R. W., \& Elder, L. (2014). Critical thinking: Tools for taking charge of your professional and personal life ( $2^{\text {nd }}$ Ed.). United States of America: Pearson Education/Prentice Hall.

Scheibe, C., \& Rogow, F. (2008). 12 basic ways to integrate media literacy and critical thinking into any curriculum (3rd Ed.). Ithaca, Project Look Sharp.

Semerci, N. (2016). The development of critical thinking disposition scale (CTHD): Study on the revision of validity and reliability. International Periodical for the Languages, Literature and History of Turkish or Turkic, 11(9), 725-740.

Wade, W. P. (2014). Bridging critical thinking and media literacy through integrated courses. CDTL Brief, 17(2), 2-5.

Willis, J., Weiser, B., \& Kirkwood, D. (2014). Bridging the gap: Meeting the needs of early childhood students by integrating technology and environmental education. International Journal of Early Childhood Environmental Education, 2(1), 140-155.

Yavuz, K. (2018). Investigation of University Students' New Media Literacy Levels (Unpublished master's thesis). Yeditepe University, İstanbul.

\section{Appendix A. Eleştirel (Kritik) Düşünme Eğilimi Ölçeği}

1-Hiç katılmıyorum 2-Çoğunlukla katılmıyorum 3-Kısmen katılıyorum 4-Çoğunlukla katılıyorum 5-Tamamen katılıyorum

1. Yaptığım işlerde ya da herhangi bir konuda zayıf olduğum noktalar varsa gidermeye çalışırım.

2. Davranışlarımın diğer kişileri nasıl etkilediğinin farkındayım.

3. Anlatılanlarda ya da okuduklarımda bilgiler arasındaki zıtlıkları bulabilirim.

4. Alanımla ilgili bilgileri genişletmek için uğraşırım.

5. Problemin nasıl çözüleceğine karar verdikten sonra mutlaka o çözümü denerim.

6. Benim için anlamlı olan bilgileri ve fikirleri düzenli bir şekilde organize edebilirim.

7. Herhangi bir konuda düşündüğüm zaman bir kalıba bağlı kaldığımı fark edersem bunu aşmaya çalışırım.

8. Duygularımın nasıl ve ne zaman beni etkilediğinin farkındayım.

9. Herhangi bir konuda çalışma yaparken karşıma çıkan belirsizlikleri gidermeye çalışırım. 
10. Çalışmalarımda uygun kriterleri, modelleri ya da kuralları uygularım.

11. Sözlü anlatımları kurallarına uygun olarak yapabilirim.

12. Herhangi bir şey hakkındaki düşüncelerimi açıkça ifade ederim.

13. Yaşamın diğer alanlarına ve farklı düşüncelerine karşı merak duyarım.

14. Problemleri çözerken orijinal çözüm yolları kullanırım.

15. Fikirlerin ve düşüncelerin güvenilir olup olmadığını kontrol ederim

16. Bir ödev hazırlarken gerekli olan tüm bilgilere ulaşmaya çalışırım.

17. Problemin çözümü için birden fazla farklı çözüm yolu önerebilirim.

18. Herhangi bir çalışmaya başlamadan önce verdiğim kararların beni nereye götüreceğini düşünürüm.

19. Çalışmalarımı değerlendirirken mutlaka ölçütlerden yararlanırım.

20. Herhangi bir konuda ihtiyacım olan bilgiye nasıl ulaşacağımı bilirim.

21. Olayları ya da bilgileri karşılaştırırken ayrıntılara inebilirim.

22. Öğrendiklerimi diğer alanlara uygulayabilirim.

23. Diğer insanların fikirlerini dikkatli bir şekilde dinlerim.

24. İlgilendiğim konu ile ilgili olmayan bilgilerin farkında olur ve onları ayıklarım.

25. Fikirlerini dinlediğim ya da okuduğum kişinin ne anlatmak istediğini anlayabilirim.

26. Herhangi bir yazı okuduğumda anafikri çabucak bulabilirim.

27. Kararlarımı vermeden düşüncelerimi kontrol ederim.

28. Derslerde tartışmalara katılmaktan zevk alıyorum.

29. Herhangi bir işe başlamadan ya da karar vermeden önce nasıl yapacağımı düşünür ve planlarım.

30. Problemi çözmeden önce değişik açılardan görmek için uğraşırım.

31. Karşıma çıkan zorlukları kolayca tanıyabilirim.

32. Düşünmeden önce konuşmam ve yazmam.

33. Herhangi bir olayın ardında yatan nedenleri araştırırım.

34. Bilgileri analiz ederken değişiklikleri göz önüne alırım.

35. Kararlarımdan önce uygun verileri toplarım.

36. Derslerime ve çalışmalarıma karşı dikkatimi yoğunlaştırabilirim.

37. Neden ve sonuçlarıyla problemleri objektif olarak analiz edebilirim.

38. Bilgi, düşünce ve fikirleri daha iyi anlamak için sorular sorabilirim.

39. Yaptığım ödevlere ya da işlere dört elle sarılırım.

40. Yaptığım işlerin ne olduğunu daha iyi anlayabilmek için onu önce parçalara ayırır sonra tekrar birleştiririm.

41. Kendime güvenirim.

42. Derslerimle ve derslerimin gerekleriyle sürekli ilgilenirim.

43. Herhangi bir işle uğraşırken bir engelle karşılaştığımda pes etmem.

44. Bir ödevi, projeyi ya da işi bitirdikten sonra onu değerlendiririm.

45. Yaptıklarımı genelde kusursuz ve tam yaparım. 
46. Çalışmalarımda kendi kendimi motive edebiliyorum.

47. Hiçbir şeyi diş görünüşüne göre değerlendirmem.

48. Karar vermeden önce yeterli veri toplarım.

49. Gerektiğinde esnek davranmasını bilirim.

\section{Appendix B. Yeni Medya Okuryazarlığı Anketi}

1-Hiç katılmıyorum 2-Çoğunlukla katılmıyorum 3-Kısmen katılıyorum 4-Çoğunlukla katılıyorum 5-Tamamen katılıyorum

1. Bilgisayarı kurcalarken ne olduğunu görerek, kendi kendime yeni şeyler öğrenirim.

2. Bir sorun ile karşılaştığım zaman vazgeçmeden önce genellikle birkaç farklı çözüm yolu denerim.

3. Bir sorunu çözmeye çalışırken çıkmaza girdiğimde bunu kişisel bir başarısızlık olarak değil yeni bir şeyler öğrenme firsatı olarak görüyorum.

4. İnsanların deprem veya güvenlik tahliyesi gibi kriz durumlarında ne yapacaklarını bilmeleri için simülasyonlar önemlidir.

5. Second Life, SimCity, TheSims, FIFA ve TigerWoods PGA Tour gibi simülasyon oyunlarını ve faaliyetlerini beğeniyorum.

6. Gerçek hayatta yapamayacağım şeylerin ( uzay mekiği ile aya gitmek veya savaş uçağı kullanmak gibi) simülasyonlarına katılmak isterim.

7. Çevrimiçiyken gerçekte olduğumdan farklı bir insan olduğumu hissediyorum.

8. Bazı durumlarda kendin olmaman gerekiyor.

9. Özgün bir multimedya projesi hazırlarken sevdiğim sanatçıların şarkı veya videolarından yararlanmanın yanlış bir şey olduğunu düşünmüyorum.

10. En sevdiğim ünlü, sanatçı veya grup ile ilgili bir fan videosu hazırlayacak olsam, o kişiler bu videoyu gördügünde büyük ihtimalle mutlu olurdu.

11. Gençlerin, popüler kültür ögelerini kendi özgün yolları ile kullanmayı öğrenmeleri önemlidir.

12. İçerisinde bulunduğum çevrenin zekam üzerinde önemli bir rolü var.

13. Daha zeki olmak için çevremden bir şeyler öğrenmeye devam etmem gerekir.

14. Belirli bir konuyla ilgili daha fazla bilgi edinmek istersem kime soracağımı veya ne yapacağımı bilmekte başarılıyımdır.

15. Öğrenmeme veya çalışmama yardımcı olması için yazım denetimi, hesap makinesi ve ansiklopedi gibi araçları kullanmanın önemli olduğunu düşünüyorum.

16. Müzik dinlemek veya mesaj çekmek gibi başka şeylerle ilgilenirken bir yandan da işimi başarılı bir şekilde tamamlayabiliyorum.

17. Çevremde başka şeyler olurken (örneğin insanların konuşması, televizyon, müzik,internet vb.) dikkatimin dağılmasını önleyip üzerinde çalıştığım konuya odaklanabiliyorum.

18. Bilgisayar üzerinde çalışırken aynı anda birden fazla uygulamanın açık olmasından hoşlanırım.

19. Benim jenerasyonum çoklu görev (aynı anda birden fazla iş yapmak) konusunda başarılı bir jenerasyon. 
20. İnternet ortamında bulduğum bilginin doğru ve güvenilir olup olmadığına etkin bir şekilde karar verebilirim.

21. İlgilendiğim konu ile ilgili genel bir bakış açısı elde etmek için televizyon, internet ve sosyal medya gibi birçok kaynaktan bilgi toplarım.

22. İnternette bir şeyler arayıp binlerce sonuçla karşılaştığımda hangilerinin benim için en faydalı bilgiler olduğuna etkin bir şekilde karar verebilirim.

23. Aradığım şeyi bulmak için arama motoruna doğru kelimeleri yazabilirim.

24. En sevdiğim programları, aktörleri ve müzisyenleri televizyon, magazin dergileri, internet, Facebook ve Twitter gibi farklı platformlar ve ortamlar üzerinden takip ediyorum.

25. Aynı hikayenin müzik, oyunculuk, yazı ve çizim gibi farklı yöntemlerle anlatıldığını hayal edebilirim.

26. En sevdiğim televizyon programlarının ve grupların internet sitelerini (resmi ve fanlar tarafından hazırlanan) sıklıkla ziyaret ediyorum.

27. Televizyonda gördüğüm bir şeyi merak edersem daha sonra bu konuyu internette araştırırım.

28. En sevdiğim bağlantıları veya yaratıcı çalışmalarımı Facebook, Youtube veya Twitter gibi sosyal medya sitelerinde paylaşmaktan hoşlanıyorum.

29. Sosyal medya hesaplarımda (Örn: Facebook, Twitter, Instagram, blogger vb.) s1klıkla bağlantı paylaşıyorum.

30. Online olduğumda kendimi toplumun bir parçası olarak görmekten hoşlanıyorum.

31. Arkadaşlarımla sadece gerçek hayatta değil sosyal ağlar yoluyla da bağlantıda olabilmem önemlidir.

32. İnternetteki ve/veya video oyunlarındaki deneyimim, beni farklı kişilere karşı daha anlayışı hale getirdi.

33. İnternetin, farklı geçmişlere sahip olan ve farklı yerlerden gelen kişileri tanımak konusundan çok önemli bir firsat sunduğunu düşünüyorum.

34. Dünyanın farklı yerlerindeki insanlarla çevrimiçi olarak veya sosyal medya üzerinden etkileşime geçebildiğim için mutluyum.

35. İnternette gezinerek, çevrimiçi oyunlar oynayarak, çevrimiçi topluluklara veya forumlara katılarak farklı kültürler hakkında yeni bir şeyler öğreniyorum.

36. İnternet kullanmanın ve/veya video oyunlar oynamanın insanları diğer kültürlere daha açık hale getirdiğini düşünüyorum.

37. Gözümde canlandırabildiğim şeyleri daha iyi anladığımı hissediyorum.

38. İş veya okul için bir proje hazırlarken olabildiğince çok resim, grafik ve şema kullanmaktan hoşlanıyorum.

39. Resim, grafik, şema ve diğer görsel araçlardan bilgi edinmek konusunda başarılı olduğumu düşünüyorum.

40. Google Haritalar ve/veya Google Earth gibi uygulamaların çok kullanışlı olduğunu düşünüyorum. 


\section{İngilizce öğretmen adaylarının eleştirel düşünme eğilimleri ve yeni medya}

okuryazarlığı seviyeleri arasındaki ilişki

\section{$\ddot{O} \mathbf{z}$}

Öğretmenlik mesleği doğası gereği öğretmenlerin sürekli olarak kendilerini geliştirmelerini, çağın getirdiği yenilikleri takip edip gerektirdiği yeterliliklere sahip olmalarını, kendilerini güncel tutmaların gerektirmektedir. Teknoloji başta olmak üzere birçok alanda gelişmelerin hız kazandığı çağımızda bu ihtiyaç, toplumların şekillenmelerindeki katkıları düşünüldüğünde öğretmenler için oldukça hayatidir. Son dönemde gelişen teknoloji ile birlikte öğretmenlerin ortaya çıkan yeni medya kültürünü öğrenip, derslerinde etkili kullanımları büyük önem arz eder hale gelmiştir. Diğer yandan yaşanan bu hızlı gelişmeler kavram olarak çok eskilere dayanan eleştirel düşünmenin bir beceri olarak öğretmenler tarafından kazanılması günümüzde daha önemli hala gelmiştir. $\mathrm{Bu}$ noktada bu her iki becerinin de öncelikli olarak öğretmen yetiştirme programlarında ele alınmasının önemine yönelik değerlendirmeler yapılmaktadır. Yapılan bu değerlendirmeler doğrultusunda bu çalışmada, iki vakıf üniversitesinin eğitim fakültelerinde öğrenim gören İngilizce öğretmen adaylarının eleştirel düşünme eğilimleri ile medya okuryazarlığı seviyeleri arasındaki ilişkiyi incelenmiştir. Araştırma sonucunda araştırmaya katılan adayların yüksek seviyede eleştirel düşünme ve yeni medya okuryazarlığı becerilerine sahip oldukları, bu iki beceri arasında orta düzeyde olumlu bir ilişki olduğu görülmüştür.

Anahtar sözcükler: eleştirel düşünme eğilimi; medya okuryazarlığı; İngiliz dili öğretimi

\section{AUTHOR BIODATA}

Aslı Yaren Yüzgeç is an English Instructor at TED University, English Language School. She holds a BA and MA in English language teaching.

Selim Soner Sütçü is a full-time assistant professor and chair of the Department of Translation and Interpretation at Başkent University. He gives lectures at undergraduate and graduate levels. His research interests include the use of technology in foreign language learning (CALL) and translation (CAT). 